\title{
EKSPANSI KARIR DESAINER GRAFIS MENJADI DESAINER GRAFIK BERGERAK SEBAGAI RUANG BESAR DALAM KREATIFITAS
}

\author{
Arif Yaniadi \\ Jurusan Desain Komunikasi Visual, Fakultas Komunikasi dan Multimedia, BINUS University \\ Jln. K.H. Syahdan No. 9, Kemanggisan, Palmerah, Jakarta Barat 11480
}

\begin{abstract}
Due to the development of technology in film and video in a decade, there are many opportunities for a graphic designer for more experiments in the moving images. This development brings convenience for both video technology and data transfer or video result, which allows a graphic designer not only saw one static design in print media, but make it more active and dynamic. For instance, if a logo created in motion version, this will enrich and convey the meaning behind the logo, although it appears briefly in 5 seconds duration. A graphic design does not have to be a static or passive; it can float, jump, fly, dance and also change shape into different shapes. After defining the visual elements in motion, it can be achieved stunning results. Some made by techniques which are difficult, and mostly we ask how this could be done.
\end{abstract}

Keywords: motion graphic, graphic designer, film, video, meaning

\begin{abstract}
ABSTRAK
Berkembangnya teknologi dalam dunia film dan video pada satu dekade ini, memberikan banyak peluang seorang desainer grafis untuk lebih bereksperimen dalam bentuk gambar bergerak. Perkembangan ini membuat kemudahan baik secara teknologi rekam maupun transfer data atau hasil video, yang memungkinkan seorang desainer grafis tidak lagi hanya melihat satu desain saja secara statis pada media cetak, tetapi membuatnya lebih aktif dan dinamis. Misalnya, bila sebuah Logo dibuat versi motion, hal itu dapat memperkaya dan menyampaikan makna sebenarnya di balik logo tersebut, walaupun tampil singkat dengan durasi 5 detik. Sebuah rancangan grafis tidak harus statis atau pasif; rancangan itu bisa melayang, melompat, terbang, menari dan juga berubah bentuk dari satu bentuk ke bentuk berbeda. Setelah menetapkan unsur-unsur visual dalam gerakan, dapat dicapai hasil yang menakjubkan. Beberapa dilakukan dengan teknik yang sulit, serta sering kita bertanya bagaimana hal ini dapat dilakukan.
\end{abstract}

Kata kunci: gambar bergerak, desain grafik, film, video, makna 


\section{PENDAHULUAN}

Motion graphic disebut nya atau motion graphic designerseseorang yang ahli dibidang ini, umumnya juga menguasai teknik-teknik animasi dan ilmu cinematografi, hasilnya sering digunakan dalam spot iklan, video musik dan film. namun, kadang-kadang juga dapat digunakan untuk visualisasi data atau instalasi (misalnya pada bangunan). Dalam profesi ini desainer memiliki ruang besar untuk mengeksplorasi kreativitas mereka.

Desainer motion graphic didasari bagian dari keilmuan desain grafis. seorang motion graphic designer atau motion (panggilan seorang motion graphic designer) secara umum berlatar belakang seorang designer grafis, yang telah mempelajari bagaimana prinsip-prinsip design sebagai awal karir mereka. Prinsip-prinsip ini yang sering membedakan sebuah karya antar animator dengan motion designer, seperti komposisi tata letak dalam sebuah bingkai, warna, dan penggunaan tipografi. Tanpa disadari 12 menit dari 1 jam penayangan televisi diisi oleh karya motion graphic designer; karya seni yang tidak terlihat sebagian pemirsa. Sebenarnya, karya motion graphic ini dalam satu dekade menjadi semakin rumit dan canggih berkat didukung oleh perangkat lunak. Profesi ini menjadi fenomenal dan akan terus berkembang, umumnya pada perusahaan yang berhubungan dengan dunia broadcast seperti TV station, Production \& Post house dan perusahaan IT. Peneliti mencoba meninjau dari sudut berkembangnya profesi ini, penulis meneliti tinjauan melalui penguasan disiplin ilmu tambahan yang melengkapinya, berkembangnyateknologi editing, media tayang, media alternatif, dan peralatan pendukung.

Tujuan dan manfaat dari penelitian ini antara lain untuk memberikan asupan cara bagaimana seorang desainer grafis dapat mempersiapkan diri mengembangkan keilmuaannya untuk menjadi seorang motion desain. Manfaat penelitian ini yaitu berupa saran atau usulan terhadap matakuliah yang telah mendukung arah profesi ini khususnya audio visual lebih mengacu materi tentang motion graphic.

\section{METODE}

Metode yang akan digunakan dalam penelitian ini adalah metode observasi pengamatan melalui, kunjungan ke beberapa rumah produksi, departemen kreatif pada stasiun TV, paska produksi serta studi kepustakaan dengan melakukan riset pustaka. Metode observasi, pengamatan terhadap mereka yang berprofesi ini, pendataan pekerjaan pribadi dengan melihat prosentase penerapan motion graphic disetiap pekerjaan yang telah peneliti lakukan dalam sepuluh tahun terakhir. Melalui penelitian pustaka beberapa pustaka yang peneliti gunakan dalam penelitian ini.

\section{PEMBAHASAN}

\section{Sejarah}

Sejarah motion graphic sangat erat hubungannya dengan sejarah pembuatan film animasi dan bagaimana gambar bergerak itu ditemui. Prekusor (Gambar 1a) animasi pertama ditemui disebuah lukisan goa, yang terdapat lima buah gambar seekor binatang berkaki empat dengan gambaran kaki yang berbeda, sangat jelas lukisan goa ini ingin memperlihatkan sesuatu yang berlari, melalui serangkaian gambar yang membentuk gerakan dengan istilah prekusor, pada animasi modern hal ini tidak dapat disebut sebuah animasi, walaupun para seniman berusaha untuk memberikan gambaran bergerak. 
Zoetrope (Gambar 1b) adalah perangkat yang menciptakan citra gambar bergerak. The zoetrope dasar paling awal diciptakan di China sekitar 180 Masehi oleh penemu Ting Huan, terbuat dari panel kertas tembus, Huan menggantungkan perangkat ini di atas lampu. Ketika tertiup angin baling-baling berbalik naik ke bagian atas dan menciptakan putaran tertentu, pada sisi-sisi di panel dilukis dengan gambar yang berbeda sehingga akan muncul pergerakan. Zoetrope modern ini diproduksi pada tahun 1834 oleh William George Horner. Perangkat dasarnya adalah sebuah silinder dengan celah vertikal di sisi.Sekeliling tepi bagian dalam silinder terdapat serangkaian gambar di sisi berlawanan dan terdapat celah.Setelah silinder berputar, pengguna dapat melihat melalui celah-celah untuk melihat ilusi gerak.Zoetrope ini masih digunakan dalam program animasi untuk menggambarkan konsep awal animasi.

The praxinoscope (Gambar 1c), ditemukan oleh ilmuwan Perancis Charles-Émile Reynaud, adalah versi yang lebih canggih dari zoetrope. Ia menggunakan mekanisme dasar yang sama dari satu strip gambar ditempatkan pada bagian dalam silinder berputar, bukannya melihat melalui celah, namun melalui cermin stasioner di sekitar bagian dalam silinder dalam serangkaian kecil, sehingga animasi akan tinggal di tempat, dan memberikan gambar yang lebih jelas dan kualitas yang lebih baik. Reynaud juga mengembangkan versi yang lebih besar dari praxinoscope yang dapat diproyeksikan ke layar, yang disebut Optique Theatre.

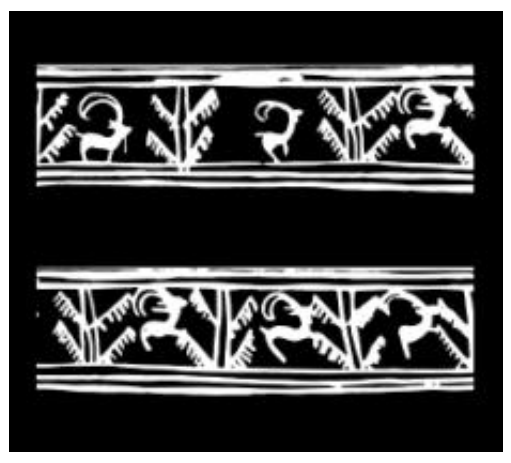

(a)

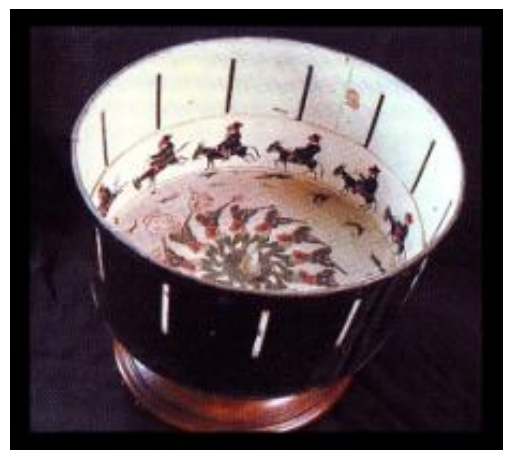

(b)

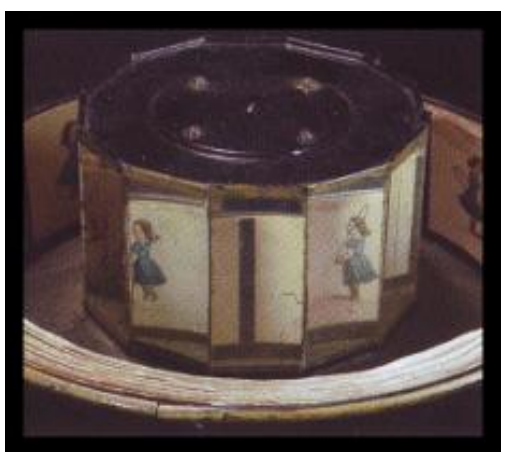

(c)

Gambar 1 (a) Prekusor; (b) Zoetrope; (c) The praxinoscope

Pada abad kedua puluh sejarah seni motion graphic dalam bioskop menempati tempat yang unik. Dipelopori Film eksperimental Tremenduos pada tahun 1920an sebuah film dipengaruhi sentuhan animator dan desainer grafis.Dalam industri film, pada 1950-an perkembangan mengisi sebagai animasi title pada sebuah film, sejak itu istilah motion graphic mulai dikenal dan merupakan bentuk baru dari profesi designer grafis.

Bila bicara tentang sejarah motion graphic, kita juga tidak dapat terlepas dari kontribusi yang sangat besar oleh Saul Bass (Gambar 2), seorang desain grafis, yg pertama dan melegendaris dalam menerap-kan sequence judul-judul beberapa film nya dengan teknik animasi ringan diantaranya credit untuk Bass's Television, Alcoa Premiere (1961), Playhouse 90 (1960) dan Static animatic logo untuk perusahaan AT\&T. Pablo Ferro, Maurice Binder, Robert Brown john (judul film James Bond), dan dua bersaudara Richard and Robert Greenberg dari R/Greenberg Associates, adalah nama-nama besar lainnya yang awal karirnya sebagai seorang designer grafis. 


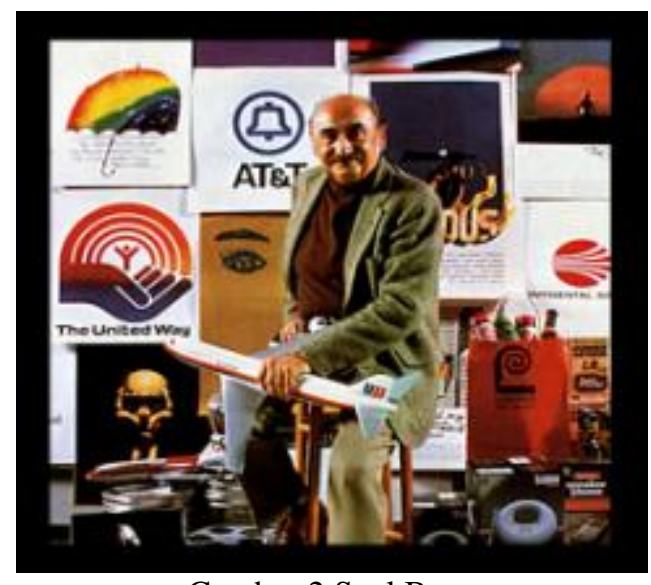

Gambar 2 Saul Bass

\section{Landasan Kuat untuk Memulai}

Sebelum memulai, diperlukan langkah-langkah awal, yaitu: (1) bertumpu pada sesuatu yang objektif; (2) menentukan target pemirsa; (3) meneliti topik; (4) memahami batasan; (5) mempertimbangkan gaya gambar; (6) brainstorming; (7) inspirasi; (8) storyboard.

Setiap desain selalu diawali sesuatu yang objektif. Tanpa objektif yang jelas, ide atau gagasan anda akan tak terarah dan hilang pada aktifitas otak kanan, sebelum menerapkannya sebaiknya seorang desainer memvisualkanya pada sebuah kertas diikuti dengan bahasa yang jelas dan mudah dimengerti. Keberhasilan komunikasi visual adalah dapat memfasilitasi reaksi pemirsa, yang diharapkan sesuatu difinisi yang jelas terhadap pemirsa, umumnya individu-individu yang bergerak pada dunia pemasaran lebih piawai dan mengetahui cara menginden-tifikasikan pasarnya, hal ini juga harus dilakukan oleh seorang desainer.

Konsep yang menarik dan mutahir mungkin belum tentu efektif dalam komunikasi. Penelitian adalah kunci efektif untuk berkomunikasi.terjun terlalu cepat ke bentuk kreatif menjadi sangat bahaya, membuang waktu dan energi pada ide-ide dinamis yang tidak memilki relefansi kuat pada tujuan akhir pekerjaan. Diawali analisis subjek akan membuat perubahan dan masukan penting sebelum anda memulai. Banyak dari seorang desainer grafis yang sukses bercita-cita untuk melampaui potensi mereka sendiri, gairah kreativitas mendorong mereka untuk menjadi lebih baik apa yang telah mereka lakukan. Mereka menciptakan seni bukan karena mereka ingin, lebih dari hasrat mereka untuk lebih dihargai melalui karyanya.

Ada beberapa gaya desain untuk dipilih dari foto, grafis, tipografi, ilustrasi, abstrak, dan sebagainya, kategori-kategori gambar dapat mengambil gaya visual yang berbeda graphic, tekstur, sketsa, atau campuran. Sementara itu, brainstorming adalah langkah awal dalam menghasilkan ide. Brainstorming dalam kondisi kondusif sangat mempengaruhi hasilnya, gangguan tidak perlu sesegera mungkin untuk dihindari, ketenangan Susana santai, beberapa orang memilih mendengarkan musik untuk mendukungnya dan beberapa memerlukan ketenangan dan konsentrasi tinggi. Kemudian, inspirasi, merupakan kekuatan motivasi dalam berinovasi, menggali sebanyak-banyaknya memberikan gambaran baru dalam ide anda dalam menemukan sesuatu yang baru.

Mempertimbangkan kondisi lingkungan yang akan dibentuk menjadi penting dalam motion design,mengetahui kontent cerita mempengaruhi apa yang harus kita lakukan, setiap bagian harus dipertimbangkan, apakah background harus selalu bergerak atau berganti setiap waktu, bentuk apa yang cocok untuk bagian depan, bagaimana animasi harus bergerak, meng-gunakan dua atau tiga dimensi untuk membentuk ini, pencahayaan, lalu mempertimbangkan efek tertentu, pergerakan kamera, semua ini penting dituangkan dalam storyboard, sejak menit pertama sampai dengan 
berkahirnya film, storyboard sama halnya dengan selembar sketsa dalam dunia printing, storyboard sangat membantu bagaimana kita akan menyajikan sebuah tayangan, dan menghindari prespektif yang tidak kita inginkan. Langkah-langkah di atas adalah langkah dasar yang harus dilewati seolah desainer motion graphic, namun bagi seorang motion designer memilki implementasi yang berbeda, langkah diatas akan lebih rumit.

\section{Tahap Motion Graphic}

Dalam motion graphic, unsur pergerakan akan mendominasi sebuah tampilan, tetapi hal yang terpenting adalah dukungan konten. Konten menjadi awal dari apa yang akan kita lakukan kelangkah berikutnya, seringkali bagi mereka langsung merancang bagaimana pergerakan, kenyataannya konten sangat mempengaruhi bagaimana gerakan seharusnya dilakukan. Pra produksi sebagai tahapan awal dimana tema, ide cerita dan pesan apa yang akan disampaikan umumnya tahap ini dituangkan dalam bentuk tertulis dengan istilah storyline. Memahami storyline dengan benar dan menemukan nyawa seluruh cerita memudahkan pemirsa untuk mengerti rangkaian gambar yang dimaksud.Seorang penulis naskah adalah orang yang piawai dalam hal ini.

Menjadi motion graphic designer, tidak saja hanya piawai mengelola sebuah software composition saja, ilmu cinematography menjadi sarat mutlak, serta berfikir secara individu dan kolektif, lihat saja pembuka film Spiderman 2, kerjasama prinsip-prinsip desain begitu baik, pergerakan teks, gambar, warna, infographic, dan timming membuat menjadikan opening credit title begitu apik, hal ini di amini oleh pembuatnya Kyle Cooper, bahwa sebagai grup yang menyukai tantangan menciptakan sesuatu yang inovatif, mewujudkan pikiran klien dan membuat mereka percaya apa yang akan hasilkan, dan semua itu kami dapat dari mempelajari prinsip-prinsip design dan yang terpenting konten cerita menjadi kekuatan untuk itu.
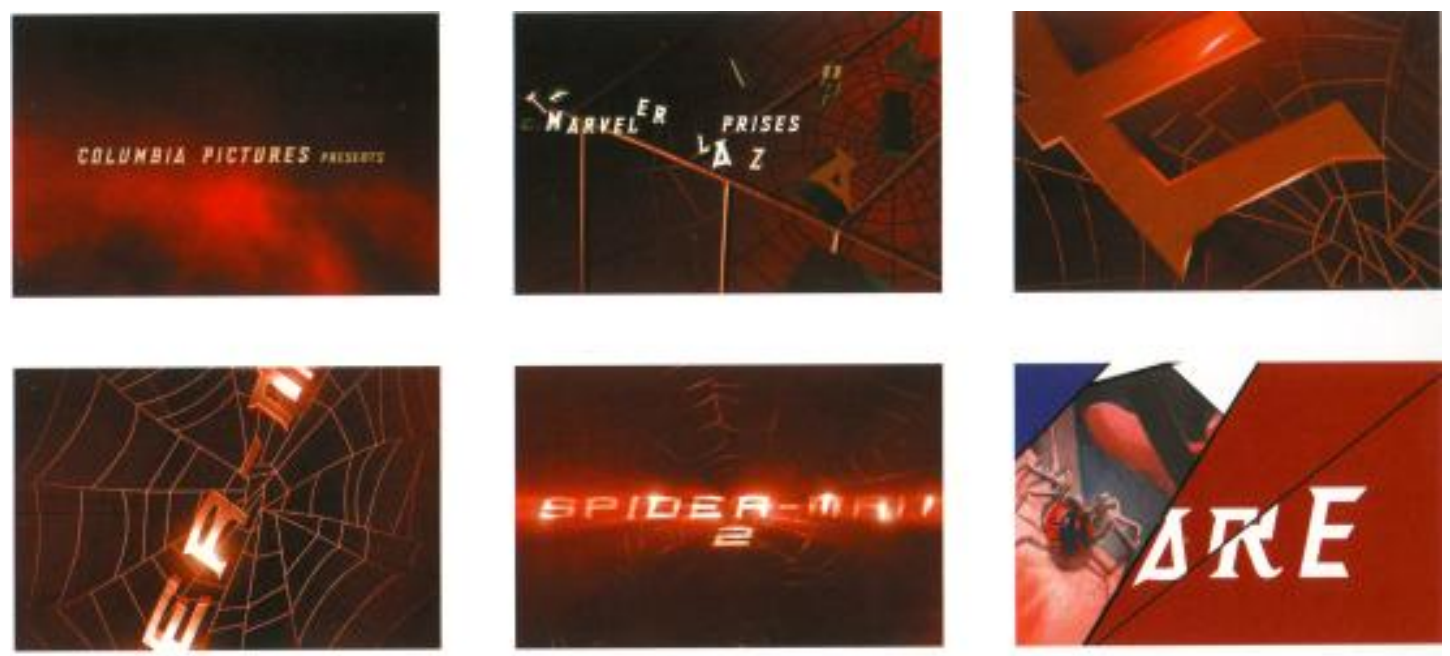

Gambar 3 Motion Graphic Spiderman 2

Kemudian, dalam tahap produksi, kemampuan mengelola pergerakan sebuah objek, membuat visual efek memilih audio dan sound efek yang sesuai,manajemen sub layar atau layer, mengatur kecepatan tempo film, pada tahapini kemampuan teknis yang dikuasai mempengaruhi hasil secara visual.Menguasai teknik editing sangat membantu ritme dan jalinan cerita yang ideal. Tahap Paska produksi merupakan tahap akhir dari perjalanan sebuah karya motion designer untuk siap tayang atau menuju on-line menggabungkan unsur yang telah dibuat pada tahap sebelumnya, seperti: gambar, animasi, efek suara, efek visual, musik pendukung, voice over menjadi satu kesatuan yang utuh dan siap untuk ditayangkan. 


\section{Motion Graphic pada Media dan Ruang Alternatif}

Sejak tahun 1950, urutan judul film telah dirancang untuk menciptakan konteks film dan membangkitkan dan antisipasi penonton acara yang akan terungkap. Dalam tahun-tahun terakhir, jaringan televisi telah menjadi semakin sadar mutu tanyangan atau gambar, akanmeningkatkan persaingan tuntutan pemirsa telah mendorong kebutuhan motion graphic secaraon-air yang lebih canggih dan menarik. Hal ini dibuktikan dalam identifikasi stasiun (atau stasiun ID), opening bumper, Interstice program, promosi televisi itu sendiri, iklan layanan masyarakat, dan videoklip.

Opening bumper merupakan sebuah program, khususnya program-program berita dirancang dengan apik untuk menginformasikan kepada pemirsa, tentang cerita atau program tanyang yang akan dating. Motion graphic designer sering memadukan live-action, fotografi, tipografi, elemen grafis (termasuk identitas stasiun) untuk meningkatkan nilai hiburan siaran. mempromosikan program tertentu. rancangan harus menunjukkan sinergi visual. Interstice adalah mini program yang muncul antara program atau acara lainnya. Beberapa didesain untuk menyoroti isu-isu kunci, orang, atau peristiwa, sebagai contoh program infotaiment, sementara yang lain berfungsi untuk mempromosikan program yang lain dengan membuat link dengan sebuah acara yang ada.

Kampanye televisi telah ada sejak 1970-an dan telah membuka peluang bagi departement artistik membutuhkan banyak motion graphic designer. Motion grafis memainkan peranan yang semakin penting pada dunia pertelevisian, seperti pada Gambar 4 dan 5. Terakhir, motion graphic designer dapat menciptakan persepsi yang baik maupun buruk bagi station TV tersebut.

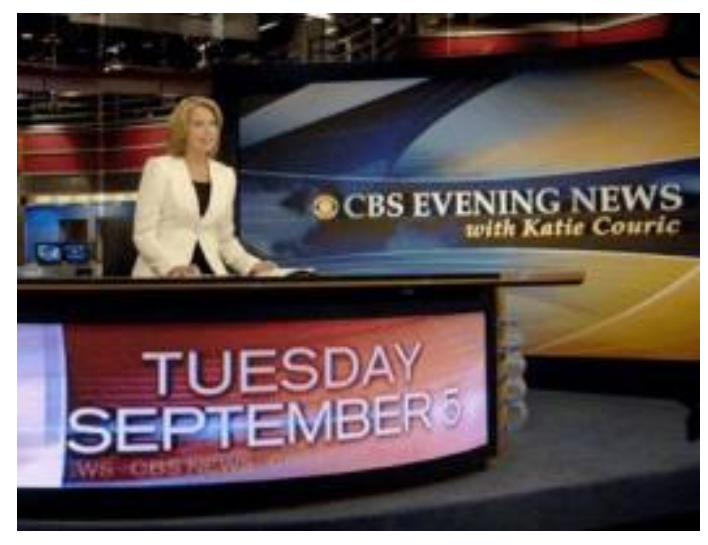

Gambar 4 Salah Satu Penempatan Media Motion Graphic Di Station TV

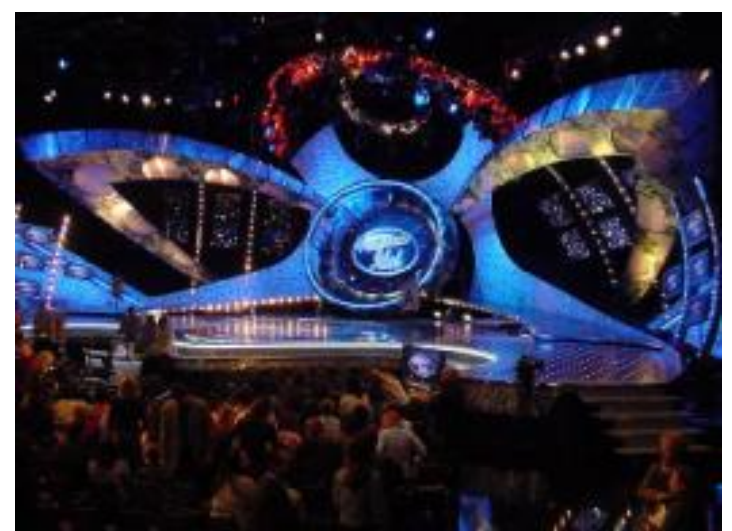

Gambar 5 Panggung American Idol Memanfaatkan Efek Visual Motion Graphic

Sementara itu, media interaktif dapat mengarahkan informasi linier menjadi struktur, percabangan non sekuensial, yang memungkinkan peran pengguna untuk menjadi aktif. Memasukkan unsur motion graphic menjadi sebuah antarmuka atau interface, hal inimemberikan motion graphic designer peluang untuk melatih bakat mereka di luar layar film dan televisi. Perkembangan koneksi bandwidth yang lebih tinggi dan video streaming telah membuat prospek motion pada web menjadi menarik. Saat ini, format web yang paling umum animasi adalah java, animasi GIF, Flash, Quick Time, Windows Media Player, dan Real Player. Sejak 1990-an, applet Java telah digunakan untuk menghasilkan animasi interaktif dalam desain halaman web.

Meskipun independensi, platform Java memastikan bahwa mereka dapat berjalan seiring dengan perkembangan perangkat keras yang didukung oleh sistem operasi, namun banyak desainer menghindari Java script karena memerlukan pengetahuan pemrograman yang rumit dan memilih program instant seperti Adobe Flash. 
GIF animasi terus menjadi pilihan berteknologi rendah populer sejak semua browser mendukung format GIF. Selain itu, GIF animasi tidak memerlukan plug-in untuk melihat, dan keterampilan pemrograman tidak diperlukan. Banyak desainer menganggap Flash untuk menjadi alat animasi yang paling efektif untuk menyampaikan konten interaktif berbasis vektor ke halaman web, karena kapasitas untuk playback layar penuh pada semua ukuran monitor dan platform dan kemampuannya untuk mengatur skala gambar vektor tanpa menurunkan resolusi. Actionscript, Flash bahasa pemrograman berorientasi objek, menawarkan kemungkinan yang tak terbatas untuk mengintegrasikan interaktivitas dan motion. Meskipun unggul, konten Flash bisa sulit untuk diperbarui. Animasi DHTML diakui oleh sebagian besar web browser dan tidak mengharuskan pengguna untuk men-download komponen tambahan.

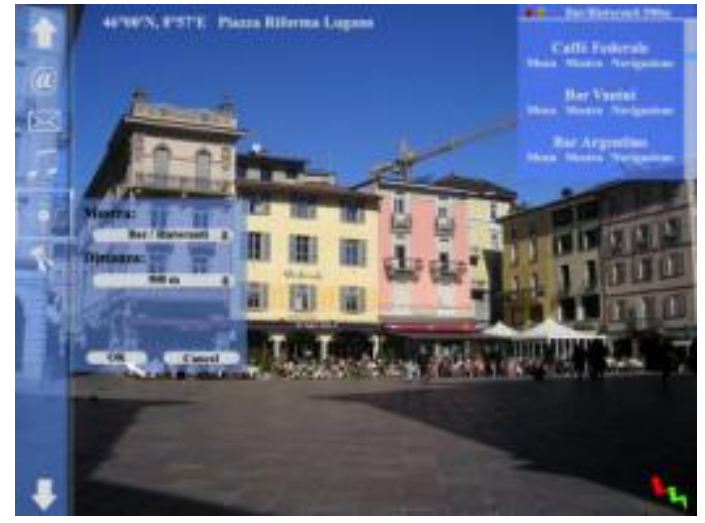

Gambar 7 Digital Signage Augmented Reality

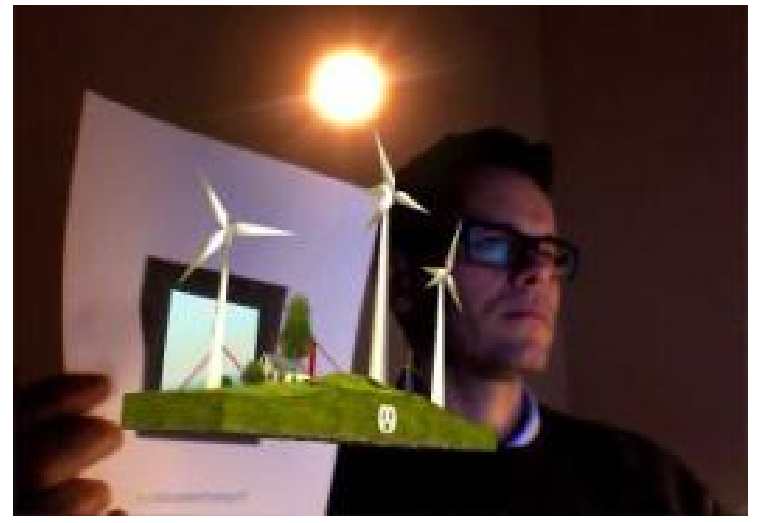

Gambar 8 Augmented Reality dengan Code

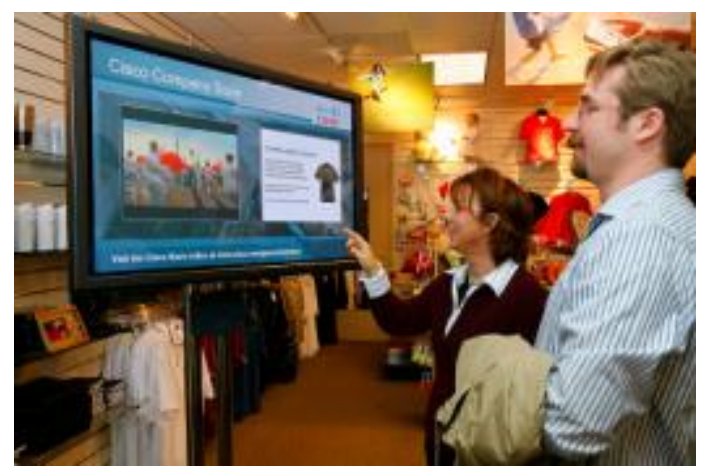

Gambar 9 Digital Signage Public Space

Namun, terbatas dalam kemampuan animasi. Quicktime, windows Media Player, dan format RealPlayer dapat memberikan data video melalui Web melalui download atau streaming. Karena video adalah salah satu aset yang memerlukan bandwidth-intensif, kesuksesan desain mendukung navigasi dan pengguna langsung tanpa harus melalui kompleksitas interface. Transisi animasi dapat membantu pengguna bergerak di antara berbagai kanal.Demikian juga, halaman spalsh animasi dapat mengatur suasana hati, memperkuat merek, dan menarik pengunjung untuk memasuki sebuah situs. Penerapan motion graphic ke dalam desain banner bisa membantu menarik pengguna potensial pada sebuah situs. Melakukan komunikasi langsung yang paling efektif dalam periklanan, animasi harus tetap sederhana dan halus. Banner animasi sering diuji pada berbagai browser dan platform, melalui kecepatan koneksi untuk memastikan hasil yang maksimal dan konsisten. Iklan web, seperti iklan televisi, yang dirancang untuk membuat pemirsa mengetahui informasi yang mungkin akan terjawab dalam iklan banner. 
Desain format, seperti interstisi dan iklan berbasis video dihadapkan dengan tantangan untuk dapat diakes lebih cepatdan dapatmenampilkan gambar resolusi tinggi dan informasi dinamis. Teknologi touchscreen integration, touchless, augmented reality dan meningkatnya popularitas ponsel pintar dan game konsol portabel terus mendorong kebutuhan motion graphic designer

Motion Graphics juga menjadi komponen integral dari multimedia menulis media. Dalam pendidikan, kursus pelatihan berbasis komputer dan buku referensi memungkinkan pengguna untuk mengakses berbagai format informasi. Dalam industri hiburan, pengalaman sinematik menjadi lebih interaktif, dan permintaan untuk desainer video game telah meningkat. Seperti web, struktur menu nonlinier dari judul DVD video dapat diciptakan lebih menarik, pengalaman interaktif. Integrasi gerak ke dalam desain menu DVD dapat meningkatkan proses navigasi dan menambah pengalaman menonton. Menu Motion dapat disesuaikan untuk disisipkan animasi atau preview bergerak dari isi DVD. Mereka juga dapat digabungkan ke dalam latar belakang atau dirancang agar sesuai dengan bentuk non reguler. Pendekatan ini dapat membuka banyak kemungkinan desain menarik yang melepaskan diri dari template yang ada di pasar.

Potensi grafis gerak di dunia fisik kita telah menyadari dan membantu untuk membentuk lanskap desain lingkungan.Teknologi baru digital yang memainkan peran yang lebih besar dalam membentuk lanskap, visual publik. Sistem dinding Video, yang dapat menampilkan gambar yang sangat besar tanpa mengorbankan resolusi layar, yang berkembang di seluruh dunia di hampir setiap arena, termasuk pameran dagang, showroom, klub malam, toko retail, restoran, dan arena olahraga. Teknologi tampilan yang baru telah menggunakan cahaya untuk mengubah ruang publik, membangun merek, dan aktifkan imajinasi dengan membiarkan gerak grafis menjadi bagian fisik dari lingkungan kita. Light Emitting Dioda (LED) telah semakin menjadi pilihan arsitek dan desainer lingkungan yang mengubah lingkungan dengan cahaya pintar. Tidak seperti LCD tradisional atau layar plasma, LED display dapat dibangun untuk setiap ukuran dan rasio aspek untuk memungkinkan konfigurasi geometrik disesuaikan. Pajangan ini terlihat di jendela depan, karena mereka cukup terang untuk bersaing dengan sinar matahari, dan dapat dilihat dari jarak kurang dari 3 meter.

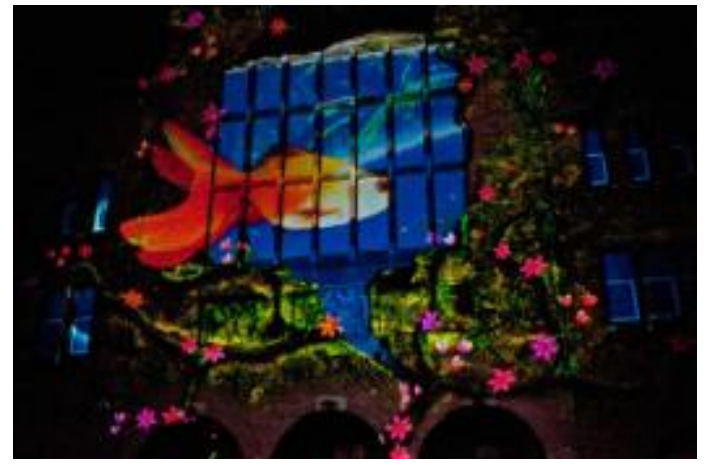

Gambar 10 Projection Mapping

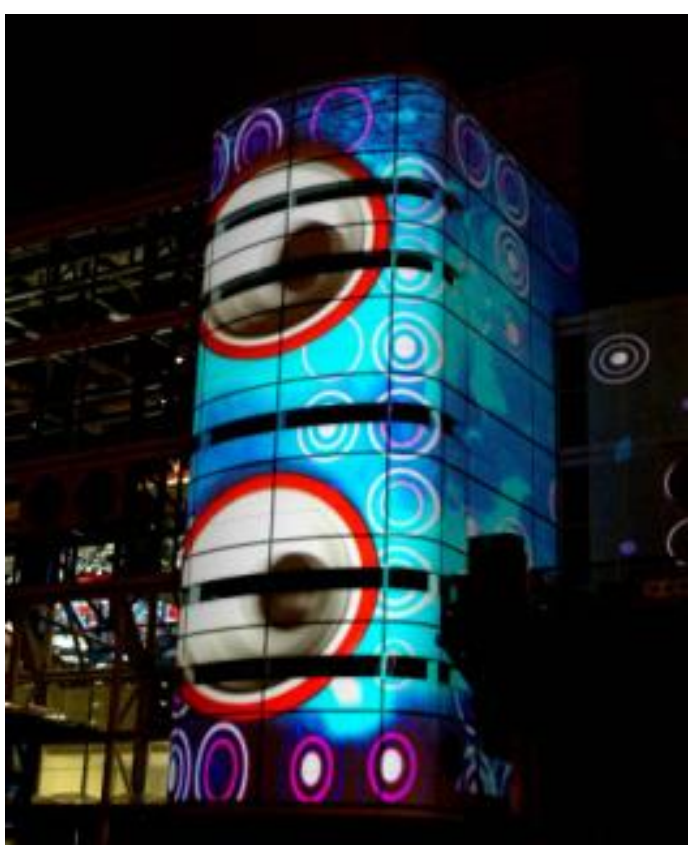

Gambar 11 Urban Space 3D Projection Mapping 


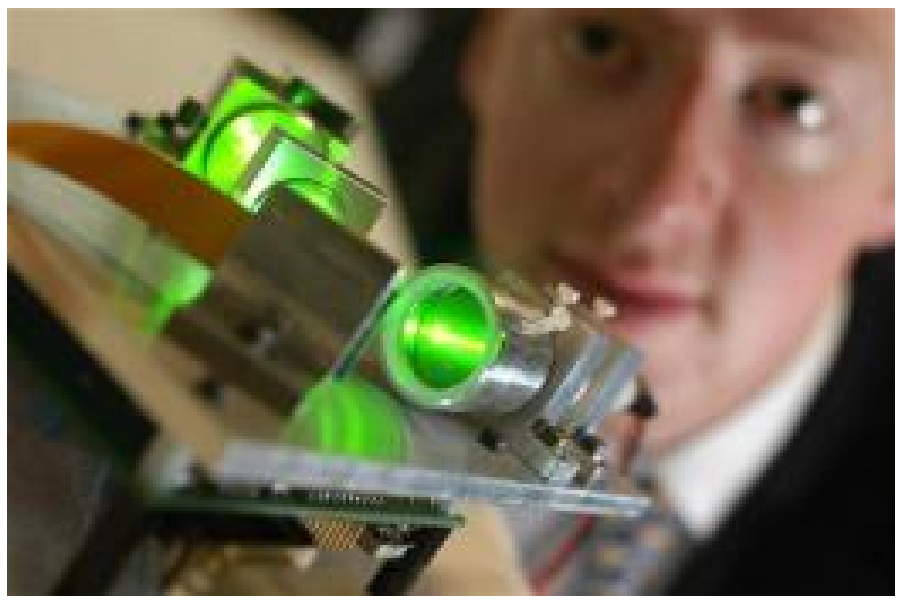

Gambar 11 Hologram Projector

Motion Graphics di ruang interior telah menjadi komponen penting dalam menentukan mood dan suasana. Dalam lobi-lobi korporasi atau ruang tunggu, misalnya, mereka dapat digunakan untuk memperkuat merek, mengubah konten untuk mendukung berbagai pesan, dan tentukan suasana yang mungkin tak terjangkau dengan media lain, namun tetap menjaga integritas desain ruang. Di ruang ritel dan acara, mereka dapat menambah dimensi unik pada ruang, memberikan drama di entrance ways, dan menarik lalu lintas di luar dengan menghadirkan konten dalam jendela layar.

Kasino, restoran, dan hotel, juga telah menggunakan motion graphic untuk merangsang interaksi tamu dan menyediakan konten yang unik sebagai pengganti untuk program televisi biasa. Lingkungan immersive dirancang untuk berbaur dunia fisik dan imajiner di mana gambar bergerak, teks, dan audio dapat menanggapi manusia. Kualitas artistik dan ekspresif gerak lebih sering tampil dalam desain pameran, ritel spasi, dan instalasi seni, serta di lingkungan masyarakat yang kompleks seperti bandara dan taman hiburan. tambahan, mereka memainkan peran yang lebih besar dalam mengakomodasi instalasi arsitektur besar-besaran dan sistem signage digital, yang mampu memberikan konten ke beberapa lokasi.

Integrasi motion graphic ke seni pertunjukan live performance meningkat cukup tinggi selama dekade terakhir. Seperti pementasan menjadi lebih boros, prospek layar video raksasa diterangi dan fasilitas pencahayaan rumit kata lain untuk metode baru choreographing data untuk sinkronisasi dengan pemandangan berubah atau musik yang dilakukan. Meskipun potensi penuh dari motion graphic dalam ruang immersive virtual saat ini masih harus direalisasikan, potensi mereka dalam augmented reality saat ini tampaknya lebih menjanjikan.

\section{PENUTUP}

Motion designer sebuah profesi masa depan? Internet, Handphone, PDA dan interactive televisi, membuka pintu selebar-lebarnya untuk profesi ini. Lalu teknologi medianya yaitu touchless, gesture-recognition, voice comment, augmented reality, virtual reality, urban space media, adalah tempat seorang motion graphic designer untuk bereksperimen. Adalah tugas lembaga pendidikan untuk membuat kurikulum yang benar sesuai dengan perkembangan teknologi guna mendukung lahirnya motion designer yang benar dan berfikir secara konseptual serta keilmuaan yang mendukung. 


\section{DAFTAR PUSTAKA}

Drate, S., Robbins, D., \& Salavetz, J. (2006). Motion by design. UK: Laurence King.

Krasner, J. (2008). Motion graphic design. Ocford, UK: Elsevier. 